\title{
neofilolog
}

Czasopismo Polskiego Towarzystwa Neofilologicznego

ISSN 1429-2173, 2018, NR 50/1, 11-28

http://dx.doi.org/10.14746/n.2018.50.1.2

http://poltowneo.org/

Katarzyna Karpińska-Szaj

Instytut Filologii Romańskiej UAM kataszaj@amu.edu.pl

Bemadeta Wojciedhowska Instytut Filologii Romańskiej UAM bewoj@amu.edu.pl

\section{PRZEFORMU OWANIE JAKO NARZĘDZIE BADAWCZE W AKWIZYCJI JĘZYKA I GLOTTODYDAKTYCE}

\section{Reformulation as a research instrument in language acquisition and language education studies}

The subject of this article is the use of reformulation, the instrument of language acquisition research, in studies on language teaching and learning. Incorporating reformulation into the methodological repertoire of language education research requires a clear definition of differences in the subject-matter and in objectives of research between the two disciplines, in order to clearly capture the potential and limitations of this tool. This article will consider the innovative potential of reformulation at both the research level and the didactic level, at various stages of development of communicative competencies in a foreign language.

Keywords: research perspective, language acquisition, interdisciplinarity in language education studies, reformulation

Słowa kluczowe: perspektywa badawcza, akwizycja języka, interdyscyplinarność w glottodydaktyce, przeformułowanie 


\section{Uwagi wstępne}

Glottodydaktyka jako stosunkowo młoda dziedzina nauki prowadzi ciągłą refleksję nad własną metodologią badań. W tej metaglottodydaktycznej refleksji jest również miejsce na krytyczną analizę metod badawczych stosowanych w dziedzinach pokrewnych oraz na rozważenie możliwości i warunków zapożyczenia wybranych narzędzi dla celów sobie właściwych. Przedmiotem niniejszego artykułu jest wykorzystanie w glottodydaktyce narzędzia stosowanego w badaniach nad akwizycją języka, jakim jest przeformułowanie. W łączenie przeformułowania do repertuaru metodologicznego glottodydaktyki wymaga wyraźnego zdefiniowania różnic w przedmiocie i celach badawczych obu wspomnianych dyscyplin tak, by wyraźnie uchwycić potencjał i ograniczenia tego narzędzia.

Badania nad akwizycją języka pierwszego dążą do rozwijania wiedzy o nabywaniu językowych kompetencji komunikacyjnych na kolejnych etapach rozwoju poznaw czego dziecka. Skupiają się one na uchwyceniu, opisie i wyłonieniu specyfiki powiązań między osobowymi (wrodzonymi) procesami budowaniajęzyka w funkcji komunikacyjnej i reprezentatywnej z czynnikami zewnętrznymi (społeczno-kulturowymi). Badawczym programem glottodydaktyki jest natomiast rozwój językowych kompetencji komunikacyjnych uczących się języka obcego. Zważywszy na kontekst uczenia się/nauczania, rozwijanie kompetencji zależne jest od stymulacji językowej i osobistych celów uczenia się, a także od potencjału językowego/ poznawczego osoby uczącej się wynikającego z uprzednich doświad czeń uczenia się języków w ogóle (języka ojczystego, a także kolejnych języków obcych). Wspólne natomiast dla akwizycjonistów i glottodydaktyków jest pytanie, jak użytkownik języka konceptual izuje formę i znaczenie, żeby móc tworzyć wypowiedzi zgodne z normami społecznego komunikowania (gatunki i typy dyskursu) obowiązującymi w danej sytuacji.

Wspomniana wyżej bliskość problematyki, jaką zajmuje się akwizycja języka, uzasadnia inspiracje badawcze w glottodydaktyce, z poszanowaniem odrębności i specyfiki obu tych dyscyplin. W naszym rozumieniu inspiracje te nie powinny polegać na bezpośrednim wykorzystaniu wyników w nowym/innym kontekście czy też na nowym/innym odczytaniu wniosków z badań osiągniętych analogicznymi metodami i narzędziami. Mogą one natomiast dotyczyć śledzenia i analizy stawianych pytań badaw czych oraz narzędzi używanych w dociekaniach nad przyswajaniem języka w perspektywie wyzwań uczenia się/nauczania języków obcych w konkretnych sytuacjach dydaktycznych. Wydaje się, że takie podejście upoważnia do mówienia o interdyscyplinarności badań glottodydaktycznych w przeciwieństwie do „wielodyscyplinarności” dziedziny, wynikającej li tylko ze złożoności przedmiotu, jakim jest język/dyskurs w procesie 
przyswajania/uczenia się ${ }^{1}$. W duchu tak właśnie rozumianej interdyscyplinarności postaramy się wykazać pożytek, jaki może płynąć dla glottodydaktyki ze śledzenia badań akwizycyjnych, w tym przypadku wykorzystujących przeformułowanie jako narzędzie badaw cze. Refleksji nad celami i metodologią badań towarzyszyć będą przykłady ich eksploracji prowadzonych w ramach międzynarodowego projektu La complexité linguistique de 6 à 14 ans. Acquisition, production, traitement koordynowanego przez Claire Martinot z Paryskiej Sorbony².

\section{Horyzonty badań akwizycyjnych}

Najogólniej rzecz ujmując, w badaniach akwizycyjnych widoczne są dwie perspektywy: językoznawcza, skupiona na analizie materiału językowego pozyskiwanego w produkcji werbalnej dzieci na kolejnych etapach ich rozwoju (analiza danych opiera się głównie na tzw. modelach matematycznych inspirowanych pracami językoznawczymi) i kognitywna/społeczna, skupiona na procesach generujących obserwowane zachowania językowe. Studia te odnoszą się bardziej do modelu biologicznego, a następnie także do modelu społecznokulturowego człowieka i łączą język z procesami umysłowymi. Tak złożona materia powoduje rozmaite trudności metodologiczne związane z jednej strony z organizacją i etyką badań (zob. Sopata, 2013), z drugiej zaś z doborem jasnych, weryfikowalnych kryteriów analizy danych empirycznych.

Wczesna teoria imitacji inspirowana behawioryzmem wyjaśniała nabywanie języka głównie w zakresach fonologicznym i leksykalnym. Jak wiadomo, wyjaśnienia te wzbudziły szereg kontrowersji, choć ich bezsprzecznym osiągnięciem jest zwrócenie uwagi na znaczenie jakości i ilości danych wejściowych (input) jako warunku koniecznego do przyswajania języka. Natomiast badania inspirowane językoznawstwem skupiały się przede wszystkim na nabywaniu kompetencji gramatycznej w odniesieniu do wrodzonych zdolności językowych. Perspektywa językoznaw cza wywodząca się ztradycji generatywnej zakłada istnienie kolejnych etapów rozwoju języka, których dynamika jest determinowana wiekiem oraz jakością i ilością stymulacji językowej (ekspozycji na dane wejściowe). Według modeli inspirowanych językoznawstwem generatywnym,

${ }^{1}$ Interdyscyplinarność, wielodyscyplinarność i autonomia glottodydaktyki są szeroko dyskutowane w 34 numerze czasopisma "Neofilolog" pod redakcją Haliny Widły (2010) poświęconemu w całości tej problematyce.

2 Projekt ten jest zadaniem badawczym grupy Sens Texte Informatique Histoire z Uniwersytetu Paris Sorbonne. Celem projektu jest zebranie korpusu językowego i określenie na jego podstawie potencjału językowego w poszczególnych przedziałach wiekowych dzieci zgodnie z hipotezą, wg której nabywanie języka ojczystego przez dziecko odbywa się w toku przeformułowań wypowiedzi cudzych. 
dziecko ma być wyposażone w uniwersalne własności języka, a docierające do niego bodźcie mają za zadanie ich specjalizację w obrębie danego języka.

Badania akwizycyjne nurtu kognitywistycznego, mające na celu zbudowanie modelu języka (utożsamionego z gramatyką), według którego dziecko rozwija swoje językowe kompetencje, zasadzają się na twierdzeniu, że przyswajanie języka jest „łańcuchem kolejnych rozszerzeń gramatyki dziecka, która się stopniowo wyłania z interaktywnych działań komunikacyjnych" (Tabakowska, 2016: 107), język stanowi zaś tworzący sieć wzajemnych współzależności inwentarz jednostek symbolicznych o różnym stopniu złożoności. W obszarze badań językoznawczych sytuujących się w tym nurcie, gramatyka kognitywna opisana przez Ronalda Langackera (2009) definiuje jednostki języka jako połączenie dwóch biegunów - semantycznego (znaczeniowego) i fonologicznego (formy), co oznacza, że formy nie można badać w oderwaniu od znaczenia, a między elementami sieci jednostek istnieje swoista symbolizacja (powiązanie składnika fonologicznego i semantycznego), kategoryzacja (porządkowanie jednostek według zasady „od ogółu do szczegółu”) i integracja (tworzenie złożonych jednostek symbolicznych w efekcie rutynizacji). Użytkownik języka, kierując się celem i kontekstem komunikacyjnym, tworzy wypowiedzi językowe w kategoriach wyboru z repertuaru jednostek symbolicznych, jakie mu oferuje język. Charles Fillmore, Kolberg i William Croft (za Tabakowska, 2016: 104) w swojej gramatyce konstrukcji zajmują się natomiast dynamicznym procesem rozumienia języka, w którym konstrukcje językowe zawierają jednocześnie informację syntaktyczną, semantyczną i pragmatyczną. Z tego właśnie powodu interesujący dla badań akwizycyjnych jest szczególnie ostatni okres inspiracji kognitywistyką, który przyniósł zwrot ku konstruktywizmowi w podejściu do leksykonu i gramatyki oraz integrację pojęciową na poziomie wyrażania i struktur gramatycznych (tamże: 112, zob. także Konderak, 2016: 535-545).

Rozwój takich dziedzin językoznawstwa jak pragmatyka czy analiza dyskursu doprowadził do rozszerzenia zainteresowań badawczych o kontekst społeczny. Przedmiotem badania nie jest już wyłącznie nabywanie składni czy leksyki, ale ich umiejętne wykorzystanie w różnych typach dyskursu czy rodzajach interakcji. W nurcie badań nad społeczno-pragmatyczną teorią akwizycji języka szczególnie istotne są prace amerykańskiego psychologa rozwojowego, M ichaela Tomasello $(2003,2009)$, który opisuje rodzaje zdolności poznawczych koniecznych do budowania języka: odczytywanie intencji, ustalenie relewancji, zmiany ról, rozpoznawanie prawidłowości i gramatykalizację. Nośnikami intencji komunikacyjnej są wypowiedzi jako całości, z których dziecko abstrahuje mniejsze jednostki. Aby tak się stało, konieczna jest wspólna (połączona) uwaga (ang. joint attention) ukierunkowana na intencjonalność, różnorodność postrzegania i (w konsekwencji) interpretacji rzeczywistości pozajęzykowej. Badacze tego nurtu 
zwracają także uwagę na wpływ języka (zwłaszcza struktur gramatycznych) na sposób wyrażania znaczenia ${ }^{3}$. Coraz wyraźniej formułowane jest też przekonanie, że rozwój niektórych kompetencji w języku pierwszym, w tym szczególnie metajęzykowych i metadyskursywnych, może być bardzo różny u poszczególnych dzieci w zależności od zwyczajowych sposobów komunikowania w otoczeniu dziecka: rodzinie, kulturze, kontekście społecznym (zob. Le Cunff, 2008). Ustalenie to powoduje przesunięcie punktu ciężkości z ujmowania nabywania języka wyłącznie jako przetwarzania danych obecnych w otoczeniu w kierunku uwzględnienia perspektywy społeczno-kulturowej tego procesu.

Choć podejścia badawcze nurtu kognitywistycznego i społeczno-pragmatycznego zmierzają do wyjaśnienia procesu akwizycji języka, badając poszczególne zakresy budowania językowych kompetencji komunikacyjnych, jak dotąd, nie dostarczyły wizji całościowego modelu odnoszącego się do dynamiki oddziaływania i indywidualnego kształtowania wrodzonego potencjału poznawczego dziecka oraz społeczno-kulturowych i lingwistycznych czynników środowiska. Wnioski z badań dotyczą bowiem różnorodnych kontekstów analizy, a każda z przytoczonych wyżej perspektyw naświetla proces akwizycji języka w wybranym aspekcie.

Zmiana teoretycznej perspektywy, zgodnie z którą wiedza gramatyczna jest wrodzona, na perspektywę, w której gramatyka języka abstrahowana jest z użycia, zbliża najbardziej pola badawcze akwizycji języka pierwszego i nauki języka drugiego (zob. Chenu, Jisa, 2009). Nie oznacza to jednak, że można oczekiwać usystematyzowanej teorii jako uniwersalnego i zarazem w pełni aplikowanego w badaniach pokrewnych paradygmatu naukowego (zob. także Dakowska, 2001). Trudno jest bowiem opisać proces akwizycji jako całość dynamicznie zmieniającej się konfiguracji zindywidualizowanych wpływów społeczno-kulturowych. Poszczególne elementy potencjalnego modelu przyswajania języka mogą jednak opisywać jego struktury na poszczególnych etapach rozwoju dziecka. Właśnie w tym zakresie badania akwizycyjne mogą stanowić inspirację do poszerzania i specyfikacji poszukiwań dla celów wytyczonych w dziedzinie nauczania/uczenia się języków.

\footnotetext{
${ }^{3}$ Zgodnie z obserwacjami z badań Dana Slobina (1985), czyli myślenia uruchomianego ze względu na wymogi kodu językowego w przyswajaniu języka, dzieci uczą się także specyficznych sposobów myślenia dla mówienia. Niektóre znaczenia kształtują się niezależnie od kategorii danego języka i są kwalifikowane jako znaczenia przedjęzykowe mobilizujące dziecko do poszukiwania językowej formy jego wyrażania. Jednak akwizycja znaczeń nie może być przypisywana jedynie do uprzednio ukształtowanych pojęć, na co wskazały m.in. badania M elissy Bowerman (2003). Kategorie języka otoczenia współwpływają jednak na kategorie semantyczne u dzieci, a faza przyswajania znaczeń specyficznych dla języka może pojawić się nawet na etapie przedsłownym, zob. także podsumowanie tych badań w publikacji Piotra Konderaka (2016).
} 


\section{Przeformułowanie w badaniu złożoności językowej w języku ojczystym}

Nakreślone wyżej obszary badawcze akwizycji pozwalają lepiej uchwycić specyfikę wspomnianego już we wstępie międzynarodowego projektu, a także przybliżyć dylematy metodologiczne właściwe dla badań akwizycyjnych. Poniżej przedstawiamy pokrótce metodologię projektu, by pokazać, w jaki sposób jej zastosowanie w badaniach akwizycyjnych zostało wykorzystane - zmodyfikowane i poszerzone na potrzeby badań glottodydaktycznych.

Prowadzone na Sorbonie pod kierunkiem Claire Martinot wieloletnie badania akwizycji struktur językowych u dzieci w różnych przedziałach wiekowych opierają się na językoznawczym modelu analizy, dla którego podstawą jest dystrybucjonizm w ujęciu Zelliga Harrisa (2007 [1988]). Na potrzeby badania złożoności językowej w języku pierwszym opracowano protokół badawczy, który zasadza się na przeformułowaniu opowiadania (zob. Martinot, 2016). By zbliżyć się do naturalnej sytuacji komunikacyjnej, złożone predykacje zostały wkomponowane przez badaczy w opowiadanie, które, po jednorazowym wysłuchaniu, dzieci odtwarzały ustnie. Zebrane dane poddano transkrypcji i następnie analizowano pod kątem typów przeformułowań (operacji językowych) i stopnia złożoności wykorzystanych struktur językowych. Przedmiotem analizy były więc zmiany w sposobie traktowania danych wejściowych (inputu) w wypowiedziach dzieci (outputcie). Przeformułowanie w omawianym projekcie zdefiniowano jako „proces odtworzenia wypowiedzi, w której elementy zachowane z wypowiedzi źródłowej łączą się z elementami zmodyfikowanymi w stosunku do tej wypowiedzi. Modyfikacja może dotyczyć poziomu leksykalnego, składniowego lub semantycznego" (Martinot, 2012 [1994]: 65) ${ }^{4}$. Tak rozumiane przeformułowanie odnosi się do procesów wewnątrzjęzykowych z pominięciem ich kognitywnych uwarunkowań. Chociaż

\footnotetext{
${ }^{4}$ Przeformułowanie jako narzędzie badawcze w akwizycji języka jest przede wszystkim wykorzystywane w metodach eksperymentalnych opartych na konkretnych hipotezach dotyczących ilości i jakości struktur językowych w wypowiedziach dzieci na kolejnych etapach rozwojowych, uzyskanych na podstawie materiału wyjściowego. W całościowym opisie procesu przyswajania języka użycie przeformułowania jako narzędzia badawczego nie jest jednak wystarczające, gdyż dane eksperymentalne mogą świadczyć o jakości produkowanych wypowiedzi, lecz nie tłumaczą procesów rozumienia/pojmowania języka. Oczywiście, można przeformułowane wypowiedzi dzieci interpretować także pod kątem procesów poprzedzających ich produkcję, ale implikuje to stawianie kolejnych hipotez wymagających weryfikacji eksperymentalnej. Notabene, taką weryfikacją na potrzeby budowania świadomości językowej (i w konsekwencji uczeniowej) w badaniach glottodydaktycznych może być dialog dydaktyczny/ wywiad z uczniem po wykonaniu zadania. Jednak cele tych badań mają swoją odmienną specyfikę (zob. 3).
} 
kognitywne aspekty tych procesów nie były przedmiotem modelowania w inkryminowanym projekcie, przyjęto za Lwem Wygotskim (1989 [1934]), że dziecko nie imituje, ale korzysta w twórczy, sobie właściwy sposób z obecnych w otoczeniu danych. Oznacza to pomijanie jednych elementów, wybieranie lub przekształcanie innych i wreszcie wykorzystanie ich w swojej własnej wypowiedzi. Założono, że różnica między tekstem dostarczonym a tekstem wytworzonym daje wgląd - cząstkowy - w możliwości i w zasoby językowe dziecka, ich złożoność i rozległość.

Analizę otrzymanych danych prowadzono każdorazowo w granicach poszczególnych predykacji, na które podzielono uprzednio tekst wyjściowy i analogicznie tekst przeformułowany ${ }^{5}$. Przyjęta jednostka analizy miała więc charakter stricte językowy, a nie tekstowy czy, jeszcze szerzej, dyskursywny. Eksploracja zebranego materiału odbywała się pod kątem prymarnych jednostek języka (przede wszystkim leksyki i składni) z pominięciem ich funkcji tekstowej i dyskursywnej. Przyjęte rozwiązania były spójne z celem badania, jakim była diagnoza używanych w różnych grupach wiekowych struktur pod kątem ich złożoności językowej, a nie spójności czy dyskursywnej adekwatności wypowiedzi. Te metodologiczne wybory odzwierciedlają także kategorie przeformułowań wyróżnione przez zespół badawczy, które zostały zebrane w zestawieniu 1.

Zestawienie 1.

\begin{tabular}{|c|c|c|c|}
\hline \multicolumn{4}{|c|}{$\begin{array}{c}\text { powtórzenia6 } \\
\text { zmiany znaczenia }\end{array}$} \\
\hline \multirow{3}{*}{ 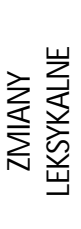 } & $\begin{array}{l}\text { parafrazy semantyczne } \\
\text { i interpretacyjne }\end{array}$ & $\begin{array}{c}\text { parafrazy formalne } \\
\text { (restrukturyzacje i transformacje) }\end{array}$ & \multirow{3}{*}{ 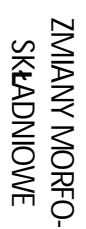 } \\
\hline & parafrazy analityczne leksykalne & parafrazy analityczne składniowe & \\
\hline & parafrazy syntetyczne leksykalne & parafrazy syntetyczne składniowe & \\
\hline
\end{tabular}

${ }^{5} \mathrm{~Np}$. pierwsza sekwencja opowiadania wyjściowego została podzielona na 4 proste predykacje:

[P1a] Pani weszła na szkolne podwórko

[P1b] później niż zwykle

[P2a] Trzymała za rękę dziewczynkę

[P2b] której nikt dotąd nie widział

${ }^{6}$ Z punku widzenia badań akwizycyjnych, zaliczenie powtórzeń do kategorii przeformułowań jest uzasadnione koniecznością mobilizacji przez dziecko posiadanych zasobów poznawczych i językowych w momencie werbalizacji. 
Typologia przeformułowań została przeprowadzona ze względu na rodzaj parafrazy (powtórzenie, zmiana znaczenia, analiza czy synteza) materiału wyjściowego, a także ze względu na główny obiekt językowy tego przeformułowania (leksykalny, syntaktyczny). Przeformułowania wg "modelu” miały charakter mikrostrukturalny i poza powtórzeniami, wyróżnione kategorie rozdzielały aspekt gramatyczny (strukturę morfosyntaktyczną) od aspektu semantycznego (w tym interpretacyjnego).

Zastosowanie wyłonionego $w$ toku badań teoretycznych modelu przeformułowania językoznawczego wymagało jednoznacznego przypisania przekształceń dokonanych przez dzieci albo do kategorii semantycznej, albo do kategorii gramatycznej. W przypadku gdy dana parafraza nosiła znamiona zintegrowanej modyfikacji w obu kategoriach, badacz musiał zdecydować, która z operacji jest dominująca. Posłużmy się przykładem, by unaocznić opisaną tu trudność w klasyfikacji materiału. Wiele dzieci przeformułowało predykację [P2b] której nikt dotąd nie widział za pomocą przymiotnika „nowa”: [...] że dziewczynka była nowa (np. Natalia, 6 lat). Przykład ten zakwalifikowano jako parafrazę syntetyczną składniową. Można jednak stwierdzić, że wyrażenie „nowa dziewczynka”, lub "nowa uczennica" ma również charakter interpretacyjny w stosunku do tekstu wyjściowego i do całego opowiadania, które dotyczy życia szkolnego, i z tego powodu mogłoby zostać zakwalifikowane jako parafraza syntetyczna semantyczna. Tego rodzaju napotkane dylematy metodologiczne zwracają uwagę na złożoność procesu przeformułowania oraz uświadamiają zakres redukcji, jakim jest on poddawany ze względu na zastosowany protokół badaw czy. Wątpliwości te nie mogą pozostać bez konsekwencji dla wyciąganych wniosków.

Metaforycznie rzecz ujmując, robiąc "fotografię" danego przedziału wiekowego $(6,8,10$ i 12 lat) otrzymano zbiór fotografii odzwierciedlających wyłącznie przyrost/zmianę kompetencji ściśle językowych, wyłonionych w przeformułowaniach dzieci. Ich zestawienie pokazało więc zachowania językowe, abstrahując od uwarunkowań wewnętrznych dziecka i celów przeformułowania. Wyniki projektu paryskiego wydają się z wielu względów wartościowe, pozwalają nie tylko wskazać na istotne różnice w złożoności wypowiedzi dzieci w zależności od wieku, lecz także dają podstawy do sformułowania pewnych tendencji ogólnych w sposobie wykorzystania materiału wyjściowego przez dzieci w swojej własnej wypowiedzi ${ }^{7}$ Ograniczenie do obserwowalnych zachowań językowych i unikanie spekulowania o wewnętrznych procesach kognitywnych zdaje się gwarantować obiektywizm. To jednak, co stanowi o atrakcyjności tej

\footnotetext{
${ }^{7} M$.in. polegają one na dążeniu do syntezy, oderwaniu się od tekstu i wykorzystywaniu środków językowych, które nie są obecne w tekście. Ze szczegółowym omówieniem badania oraz wnioskami można zapoznać się w Martinot i in. (2018).
} 
metodologii, stanowi też o jej słabości, szczególnie jeśli chcemy dowiedzieć się nie tyle tego, jakie są zachowania językowe dzieci, ale dlaczego zachowują się w taki czy inny sposób i jakie ma to znaczenie dla rozwoju ich kompetencji językowych. Kompetencje językowe odnoszą się wszak do używanych struktur o różnym stopniu złożoności, ale i do dyskursu (a więc do języka jako środka używanego zawsze w mniej lub bardziej zinstytucjonalizowanych formach komunikacji i w pewnym stopniu wybieranych na podstawie odnośnej normy społecznej). Pojawia się zatem konieczność połączenia poczynionych obserwacji i rozważenia ich bardziej całościowo w stosunku do całego tekstu i zdolności poznawczych dziecka. W tym ostatnim aspekcie niezbędne wydaje się też lepsze rozpoznanie charakterystyki dyskursywnej (a nie tylko językowej) zaproponowanego do przeformułowania tekstu, a także uchwycenie istotnych parametrów sytuacji odtwarzania oraz postrzegania tejże (role, cele itd.) przez dzieci jako determinującej w dużym stopniu ich wybory językowe. Oznacza to, że w analizie odtworzonego opowiadania można, a wręcz należy wziąć pod uwagę poziom kompetencji narracyjnej (znajomość tekstu w odniesieniu do gatunku dyskursywnego), etapu rozwojowego dziecka (rozwój poznawczy pojemność pamięci, sterowanie uwagą), celu odtwarzania czy stopnia zaangażowania w zadanie. W perspektywie rozwoju poznawczego dziecka ciekawe jest też pytanie, w jaki sposób interakcje z dzieckiem na temat przeformułowań wpływają na rozwijanie jego świadomości językowej jako użytkownika dyskursu w określonej sytuacji. I wreszcie, z pedagogicznego punku widzenia, cenne byłoby rozpoznanie, w jaki sposób wykorzystać przeformułowania dla rozwoju poznawczego i językowego dzieci w ich edukacji. Siłą rzeczy wkraczamy więc na teren kognitywistyki, a zwłaszcza jej ostatniej, interakcyjnej odsłony; ale tylko z pozoru wydawać by się mogło, że odpowiedzi na wątpliwości interpretacyjne danych uzyskanych w przytoczonym powyżej badaniu dostarczy model inspirowany językoznawstwem kognitywnym. Nie wystarczy bowiem dodać do poczynionych obserwacji uzupełnień proponowanych przez językoznawstwo kognitywne (czyli poszerzyć badania o te aspekty), choćby dlatego że metodologia powinna odpowiadać hipotezom badawczym, a te w obu przypadkach są różne.

Krytyczna ocena procedury badawczej dokonana ex post może być inspiracją do jej innowacyjnego (bo w nowej roli nauczania/uczenia się) profilowania w glottodydaktyce. Dokonana analiza zwraca uwagę na potencjał przeformułowania nie tylko jako narzędzia eksperymentalnego, lecz także jako indywidualnej strategii rozwoju językowego w kontakcie z wypowiedziami innych. Właśnie ze względu na tę charakterystykę przeformułowanie może być atrakcyjne dla glottodydaktyki pod warunkiem, że zostanie ono przedefiniowane w ramach protokotów badawczych podporządkowanych celom badawczym glottodydaktyki. 


\section{Przeformułowanie a profilowanie badań nad przyswajaniem/ uczeniem się języka w glottodydaktyce}

W perspektywie glottodydaktycznej identyfikacja pojawiających się w języku dzieci rodzajów przeformułowań / struktur językowych jest niewystarczająca, choćby dlatego że nie odzwierciedla specyfiki zadania językowego, jakie stawia nauczyciel, i postrzegania tego zadania przez ucznia. Wypracowane w perspektywie akwizycyjnej (a więc zarazem w pierwszym przytoczonym wyżej projekcie) narzędzia analizy pozwalają ex negativo dostrzec elementy, które umykają ich opisowi, a które mogą w danej sytuacji mieć znaczenie dla sposobu działania dziecka/ucznia i jego poznawczych skutków.

Przy aktualnym stanie wiedzy truizmem staje się stwierdzenie, że dydaktyka języków obcych nie może się ograniczyć do rozwijania interjęzyka (gramatyki i leksyki) i jego proceduralizacji. Jej celem jest opracowanie takich instrukcji nauczycielskich i zaproponowanie takich technik pracy, które pozwolą uczniowi działać dwutorowo: z jednej strony wyabstrahować $z$ kontekstu pewne reguły gramatyczne i leksykalne, z drugiej zaś zachować ślad ich użyć w dyskursie i stopniowo rekonstruować normy zachowań dyskursywnych właściwe dla różnych gatunków. Efektem końcowym jest zdobycie umiejętności stosowania tych norm w odniesieniu do własnych intencji w komunikacji w języku obcym.

Jeśli przyjmiemy, że reguła językowa dotyczy poziomu zdania, a więc zasad łą czenia elementów niższego rzędu oraz że norma dyskursywna określa sposoby doboru i budowania znaczenia in situ, to uświadomimy sobie wagę ich zintegrowanego nauczania w kształceniu kompetencji komunikacyjnych w języku obcym. Nasze wcześniejsze badania (Karpińska-Szaj, Wojciechowska, 2015) pozwalają Sądzić, że uwzględnienie przez ucznia charakterystyki dyskursywnej wypowiedzi może nie tylko skutecznie wspomagać jego wysiłki w nabywaniu wiedzy gramatycznej, lecz także przyczyniać się do rozwijania umiejętności obserwacji metadyskursywnej i metakognitywnej, wspierając tym samym bardziej systematyczne i ukierunkowane pozyskiwanie zasobów językowych ${ }^{8}$. Dzieje się tak wtedy, gdy proponowany do przeformułowania tekst posiada autentyczne cechy gatunkowe oraz gdy elementy językowe są świadomie przetwarzane w powiązaniu z odnośnymi schematami dyskursywnymi. W tym kontekście kompetencje dyskursywne ucznia nabyte w języku ojczystym i innych znanych już językach zyskują miano cennych zasobów w nauce kolejnego języka.

${ }^{8}$ Taką współzależność kompetencji językowej i kompetencji dyskursywnej wykazano w konkretnej sytuacji uczenia się/nauczania podsystemu morfosyntaktycznego przez początkujących studentów filologii romańskiej w badaniu opisanym przez autorki w 2015 roku (Karpińska-Szaj, Wojciechowska, 2015). 
Idąc krok dalej, trzeba powiedzieć, że w perspektywie glottodydaktycznej istotne jest uchwycenie indywidualnej dynamiki takiego właśnie uczenia się oraz czynników, które je kształtują, tak by możliwe było stworzenie odpowiednich warunków i zadań dla ich zaistnienia. Diada nauczanie/uczenie się wskazuje na łączność między tymi dwiema stronami "glottodydaktycznego medalu". To właśnie w tej relacji między uczniem a nauczycielem, wzajemnym postrzeganiu przez nich swoich ról i zadań, należy rozważać dobór materiału wejściowego (tutaj rozumianego jako modele dyskursywne) oraz zadania (jego przeformułowania w celach kształceniowych i badawczych). Stwarza to także możliwość rozpoznania indywidualnych ścieżek rozwoju ucznia, wyjaśnienia ich specyfiki i zmienności jako podstawy do opracowania sposobów ich terapeutycznego i dydaktycznego kształtowania.

Tak określona problematyka implikuje porzucenie statystyki i usytuowanie się w obszarze badania w działaniu. Badanie w działaniu, łącząc cele dydaktyczne i badawcze w ramach wspólnej sekwencji zadań, stwarza warunki do elastycznego dostosowywania kolejnych etapów dydaktyczno-badawczych do zmieniających się potrzeb i możliwości uczniów, pozwalając jednocześnie na obserwacje procesu, a nie tylko wyników.

\section{Przeformułowanie w badaniach nad przyswajaniem i uczeniem sięjęzyków obcych}

W doprecyzowaniu glottodydaktycznej funkcjonalności przeformułowania może pomóc przegląd badań inspirowanych akwizycją w dydaktyce. Technika przeformułowania była i wciąż jest przedmiotem zainteresowania badawczego i to zarówno w akwizycji języka nauczania (fr. langue de scolarisation) w kontekście szkolnym (zob. Lahire, 1992; Le Cnuff, 2008), jak i w kontekście nauczania języka obcego (np. Swain, 1985, 1995; Swain, Lapkin, 2002).

W odniesieniu do języka nauczania przedmiotów szkolnych w ostatnich latach kładzie się nacisk na rozwijanie języka w funkcji poznaw czej oraz ustalenie warunków celowego wykorzystania przeformułowania przez uczniów i nauczycieli, jako techniki wspomagającej konceptualizację. W tej perspektywie bada się interakcje dydaktyczne pod kątem rodzaju przeformułowań nauczyciela, ich roli we wzmacnianiu pozytywnych zachowań językowych uczniów, stymulowaniu ich działań metajęzykowych. Początkowo skoncentrowane na wzbogacaniu składni i leksyki badania te ewoluują w kierunku jednostek wyższego rzędu (tekstowych, dyskursywnych), a także włączają w orbitę swoich zainteresowań problematykę rozwijania umiejętności metadyskursywnych w odniesieniu do dyskursu szkolnego.

Drugi wspomniany obszar badań sytuuje się w obrębie SLA (ang. Second Language Acquisition). Jest on znacznie szerszy i ma już długą tradycję. Swoimi korzeniami sięga do koncepcji Stephena Krashena (1977, input hypothesis) rozwijanej 
później i weryfikowanej przez Richarda Schmidta (1990, noticing hypothesis), Richarda Schmidta i Sylvię Frotę (1986, noticing the gap) oraz Merrill Swain (1995, output hypothesis) ${ }^{9}$. W badaniach tych technika przeformułowania stanowi centralny element protokołu badawczego. Ponieważ prace te są powszechnie znane, ograniczymy się tutaj tylko do wskazania podstawowych rozróżnień, by na ich tle pokazać innowacyjny charakter naszej propozycji.

Otóż przeformułowanie wykorzystuje się w dwóch głównych typach zadań (zob. Thornbury, 1997; Pawlak, 2011). Pierwsze z tych zadań (ang. reformulation tasks) stosowane jest głównie w rozwijaniu kompetencji pisania i zawiera trzy główne etapy: sformułowanie tekstu w języku obcym przez ucznia, przeformułowanie tegoż tekstu przez nauczyciela z jak najwierniejszym zachowaniu znaczenia i wymogów formalnych języka, porównanie obu tekstów przez ucznia w celu dostrzeżenia elementów wymagających poprawy. Warto zauważyć, że w zadaniu tym odwrócona jest tradycyjna kolejność nauki języka, która zakłada najpierw ćwiczenie poprawności, a potem nabywanie płynności. Drugi typ zadań (ang. reconstruction tasks) polega, w swoim zasadniczym kształcie, na odtwarzaniu przeczytanego lub/i wysłuchanego tekstu modelowego przez ucznia i porównywaniu wersji oryginalnej i przekształconej. Zadanie to kieruje uwagę ucznia głównie na procesy niższego rzędu (ang. bottom up), angażując jednocześnie procesy wyższego rzędu. Towarzyszące mu interakcje uczniowskie mają na celu uświadomienie uczniowi braków środków językowych niezbędnych do oddania znaczenia wypowiedzi. W obrębie tego typu zadania wypracowano jego wiele odmian (np. dictogloss, jigsaw task, dictowatch itp.).

Oba typy zadań, chociaż nie wykluczają aspektów dyskursywnych i gatunkowych, nastawione są głównie na rozwijanie kompetencji językowej (struktur leksykalno-gramatycznych). Ich zaletą jest pobudzanie aktywności poznawczej i metapoznaw czej uczniów: selektywną uwagę i samoocenę, kierowanie uwagi zarówno na znaczenie, jak i na formę, testowanie hipotez dotyczących języka, rozwijanie współpracy w parach, samooceny itp. - a więc parametrów, które decydują o autonomii ucznia. Zastosowaniu tych zadań towarzyszą często ankiety, wywiady, pretesty i posttesty, które służą lepszemu zrozumieniu perspektywy ucznia i jego strategii uczenia się, a także sprawdzeniu efektów przeformułowania i dyskusji wokół dostrzeżonych różnic.

Podobnie jak w przedstawionej tutaj pokrótce koncepcji, również w naszej propozycji glottodydaktycznej ${ }^{10}$ przeformułowanie jest nie tylko narzędziem

\footnotetext{
${ }^{9}$ Przegląd tych badań w odniesieniu do zadania przeformułowania można znaleźć w publikacji M irosława Pawlaka (2011).

10 Została ona wypracowana w ramach projektu NCN Harmonia UM 0-2015/18/M/ HS2/00101, pt. Przyswajanie złożoności językowej w nauczaniu/uczeniu się języków
} 
badawczym, lecz także (a nawet przede wszystkim) sposobem nauczania/uczenia się. Zamierzeniem badawczym jest natomiast określenie nowych funkcjonalności przeformułowania w korzystaniu z tekstów obcojęzycznych do realizacji indywidualnych potrzeb w rozwijaniu kompetencji komunikacyjnej w języku obcym.

\section{Innowacyjne wykorzystanie przeformułowania w glottodydaktyce}

Innowacyjne wykorzystanie przeformułowania opiera się na dwóch podstawowych założeniach. Pierwsze z nich stanowi, że przeformułowanie należy do ważnych strategii uczenia się, a nastawienie na odtwarzanie (output) tekstu wejściowego przynajmniej teoretycznie aktywuje cztery wyróżnione przez M ichaela Canale'a (1983) procesy: uczenie się na błędach, uczenie się przez działanie, uczenie się przez obserwację eksperta, uczenie się w interakcji z ekspertem. Do tego repertuaru w naszym projekcie dodane zostało jeszcze uczenie się przez samoobserwację, które wykracza znacznie poza wymienione uczenie się na błędach. Implikuje ono bowiem szeroki wachlarz strategii metakognitywnych i metadyskursywnych. Wedle drugiego założenia zarówno charakterystyka dyskursywna i językowa danych wejściowych (input), jak i funkcje przeformułowania powinny zmieniać się wraz ze stopniem zaawansowania kompetencji komunikacyjnych i uczenia się.

Właśnie owa progresja w doborze tekstów wyjściowych oraz zadań ich przeformułowania stanowi główne wyzwanie badawcze postawione w projekcie. Z tego powodu protokół badaw czy skupia się na obserwacji zależności między poszczególnymi elementami sytuacji dydaktycznej stosowania techniki przeformułowania i obejmuje systematyczne zestawienie trzech parametrów:

1) cech materiału wejściowego (inputu), takich jak charakterystyka językowa (złożoność gramatyczna, leksykalna, tekstowa), łącznie z takimi, które wynikają z gatunkowego i dyskursywnego osadzenia tekstu: strukturalnych, retorycznych, stylistycznych itp.,

2) cech zadania, m.in. proporcje między rodzajami przeformułowania, które są stymulowane przez zadanie (pushing output) oraz tymi, które wynikają z twórczej interpretacji zadania odtwarzania tekstu,

3) cech ucznia, jego możliwości rozwojowych ze względu na wiek i etap edukacyjny, znane języki i wcześniejsze doświad czenie dyskursywne w języku

obcych, realizowanego na Wydziale Neofilologii Uniwersytetu im. Adama M ickiewicza (prof. Katarzyna Karpińska-Szaj, dr Agata Lewandowska, prof. Aldona Sopata, dr Bernadeta Wojciechowska) w konsorcjum z Katolickim Uniwersytetem Lubelskim (prof. Urszula Paprocka-Piotrowska - kierownik projektu) oraz we współpracy z partnerem zagranicznym (prof. Claire M artinot, Paryż-Sorbona). 
ojczystym i innych językach obcych oraz stosowanych strategii zarządzania uwagą, postaw (np. zaangażowania) i reprezentacji dotyczących materiału wyjściowego oraz uczenia się, umiejętności łączenia doświadczenia komunikacji w języku ojczystym czy w innym znanym języku obcym (np. wykorzystanie kompetencji narracyjnych czy - szerzej - doświadczenia dyskursywnego w innych językach).

Już z powyższego zestawienia wynika, że perspektywa ucznia, jego zasoby i postawy są tu kluczowe. Postrzeganie materiału wejściowego jest bowiem po części filtrowane przez zadanie, po części też zależy ono od celów, zasobów własnych oraz samego ucznia. M oże być więc mylne, skądinąd dość częste w badaniach glottodydaktycznych, przekonanie, że perspektywa nauczyciela i perspektywa ucznia są tożsame. Ostrożność w tym zakresie podyktowała włączenie do protokołu badawczego wywiadów towarzyszących zadaniom przeformułowania. Wywiady te z jednej strony mają stymulować aktywność ucznia, z drugiej zaś mają pomóc nauczycielowi dostosować zadanie tak, by zostały osiągnięte zamierzone cele dydaktyczne oraz by mieć wgląd w działania uczeniowe poszczególnych osób. Wywiady mają charakter dialogu dydaktycznego, nakierowane są na to, aby uczeń sam odkrywał swoje zasoby i umiał je oszacować oraz rozwijać.

Podsumowując, nowy model analizy przeformułowań w kontekście nauczania/ uczenia się języków obcych opiera się na konfrontowaniu badań ilościowych i jakościowych językowych konstrukcji złożonych używanych w przeformułowaniach dzieci w powiązaniu z elementami z różnych wyżej wymienionych poziomów analizy.

\section{Wybrane konteksty empiryczne wykorzystania przeformułowania w nauce języka obcego}

Wskazany potencjał badań nad przyswajaniem/rozwijaniem językowych kompetencji komunikacyjnych inspirowanych badaniami akwizycyjnymi i zasadzającymi się na przeformułowaniu zamierzamy uwzględnić w trzech sytuacjach dydaktycznych, które są jednocześnie sytuacjami badania w działaniu.

1. Wykorzystanie korpusów językowych zwartych, krótkich wypowiedzi uczniów na poziomie początkującym (III i VI klasa szkoły podstawowej). Chodzi tutaj o wplatanie wcześniej ćwiczonych struktur językowych do dłuższych, samodzielnie tworzonych przez dzieci wypowiedzi. Ze względu na wczesny etap nauczania języka obcego szczególnie duże znaczenie w tej sytuacji badawczej, która jest jednocześnie sytuacją dydaktyczną, mają przeformułowania zakwalifikowane do kategorii powtórzeń, gdyż to właśnie ten rodzaj parafrazy wydaje się najbardziej odpowiedni dla dominującej na tym etapie pamięci mechanicznej i stosunkowo niskiej 
kontroli elementów formalnych wypowiedzi. Analiza parafraz ma duże znaczenie w badaniach diagnostycznych dla celów opisu zachowań językowych w szkolnej nauce języka na wczesnych etapach edukacyjnych i ich przełożenia na konkretne działania dydaktyczne. Istotne jest przede wszystkim zwrócenie uwagi na sposoby monitorowania wypowiedzi własnych przez uczniów. Dlatego wypowiedzi dzieci są nagrywane, a następnie analizowane wraz znimi pod kątem stopnia rozwoju kompetencji metajęzykowych (sprawności użycia wybranych elementów leksykalno-gramatycznych) i formalnych (czuwanie nad spójnością i po prawnością wypowiedzi). Przeformułowanie jest w tej sytuacji strategią uczenia się podstawowych struktur językowych ${ }^{11}$.

2. Wykorzystanie korpusów językowych zawierających przeformułowane teksty dłuższe (opowiadanie) w sytuacji nauki drugiego języka obcego w celu rozwijania kompetencji uczenia się języków poprzez rozwijanie świadomości metajęzykowej i metadyskursywnej zasadzającej się na wykorzystaniu potencjału językowego i uczeniowego zdobytego w trakcie nauki pierwszego języka obcego. Produkcje uczniów (przeformułowany tekst) są w tym protokole analizowane w odniesieniu do poziomów zewnętrznych, normatywnych, zdeterminowanych przez gatunek, i wewnętrznych, personalnych, zdeterminowanych przez cechy osoby ucznia (poziom kompetencji dyskursywnej, zakres doświadczeń językowych, posiadanie środków językowych i dysponowanie nimi, wiedza ogólna itd.). Zgromadzony materiał korpusowy ma być punktem wyjścia do interwencji dydaktycznej opartej na dialogu dydaktycznym, w którym poddawane są refleksji transferowane elementy leksykalne, gramatyczne oraz znajomość schematu formalnego i schematu treści produkowanego tekstu. Chodzi także o lepsze zrozumienie tego, jak uczniowie korzystają z wiedzy gramatycznej, tekstowej i dyskursywnej zdobytej w innych kontekstach do ewentualnego kompensowania niedoborów w języku obcym (w naszym przypadku głównie wykorzystanie doświadczenia w uczeniu się języka angielskiego w celu kompensowania niedoborów w języku niemieckim na trzecim etapie edukacyjnym).

3. Wykorzystanie przeformułowania jako treningu strategicznego na potrzeby konstruowania tekstów naukowych, na przykładzie studiów filologicznych. To jedna z tych sytuacji dyskursywnych, w których uczniowie

${ }^{11}$ Dla nauczyciela takie działania mają też dużą wartość diagnostyczną w edukacji uczniów ze specjalnymi potrzebami edukacyjnymi, gdyż informują o ewentualnych niedoborach językowych i komunikacyjnych oraz umożliwiają kompensowanie pojawiających się trudności poprzez uświadomienie ich specyfiki (zob. Karpińska-Szaj, 2015). 
mają niewielkie doświadczenie w języku ojczystym i w innych językach obcych, mogą więc tylko w ograniczony sposób wspomagać się w realizacji zadania odtwarzania zasobami dyskursywnymi. W zadaniu tym materiałem wejściowym (inputem) są artykuły naukowe z dziedziny specjalizacji studenta. Odtwarzanie poszczególnych części artykułu i omawianie napotkanych trudności ma na celu łączenie kompetencji dyskursywnych i językowych, a więc rozpoznawania i uwzględniania poszczególnych elementów artykułu: postawienie problemu, uzasadnienie, wskazanie na ramy teoretyczne proponowanego rozważania, zapowiedź planu, podstawowe definicje i opozycje, progresja w rozwijaniu rozumowania, rodzaj rozumowania (teoretyczny i raport z badań) i jego charakter argumentacyjny, wnioski. Chodzi więc nie tylko o budowanie repertuaru gotowych sformułowań i struktur językowych typowych dla stylu akademickiego, lecz także o konceptualizowanie tego gatunku wypowiedzi jako niezbędnej ramy do kierowania uwagą na istotne dla rozumienia i tworzenia wypowiedzi elementy. Celem jest zbadanie, w jaki sposób studenci w trakcie kolejnych przeformułowań artykułów budują swoją kompetencję dyskursywną, jak z niej korzystają dla lepszego rozumienia problemów teoretycznych przedstawianych w artykułach oraz jak budują swoją wiedzę z dziedziny specjalistycznej.

\section{Podsumowanie}

Przedstawiony w niniejszym artykule projekt badawczy stanowi swego rodzaju ilustrację tego, jak włączenie do refleksji dydaktycznej badań prowadzonych w dziedzinach pokrewnych wspiera precyzyjniejsze uchwycenie przedmiotu właściwego dla glottodydaktyki. Jak widać z powyższego, włączenie przeformułowania do glottodydaktyki otwiera nowe perspektywy badawcze, pozwala postawić nowe pytania, zaproponować nowe zadania i, mamy taką nadzieję, prowadzi do lepszego poznania zależności między budowaniem zasobów językowych i dyskursywnych na różnych etapach nauczania/u czenia się języka w odniesieniu do różnych sprawności.

Zdefiniowanie nowych obszarów eksploracji zostało zainspirowane przez studia nad akwizycją języka, która jako dziedzina empiryczna ukazuje proces przyswajania języka w pewnym wybranym, określonym konstruktem teoretycznym, ujęciu. Przytoczone perspektywy badań akwizycyjnych nie służą przełożeniu wniosków z niego płynących do nowego kontekstu nauczania/uczenia się języków obcych, ale prowadzą do innowacyjnego wykorzystywania procedur i narzędzi, a także hipotez badawczych, co jest możliwe poprzez sformułowanie problemów badawczych i celów badań w kategoriach właściwych dla glottodydaktyki. 


\section{BIBLIOGRAFIA}

Bowerman M. (2003), Rola predyspozycji kognitywnych w przyswajaniu systemu semantycznego (w) Dąbrowska E., Kubiński W. (red.), Akwizycja języka w świetle językoznawstwa kognitywnego. Kraków: Universitas, s. 254-313. Canale M. (1983), From communicative competence to communicative language pedagogy (w) Richards J.C., Schmidt R.W. (red.), Language and communication. London - New York: Longman, s. 2-27.

Chenu F., Jisa H. (2009), Reviewing some similarities and differences in Lland

L2 lexical development (w) Acquisition et interaction en langue étrangère. Online: http://aile. revues.org/4506 [DW 07.01.2018].

Dakowska M. (2001), Psycholingwistyczne podstawy dydaktyki języków obcych. Warszawa: Wydawnictwo Naukowe PWN.

Dąbrowska E., Kubiński W. (red.) (2003), Akwizycja języka w świetle językoznawstwa kognitywnego. Kraków: Universitas.

Harris Z.S. (2007) [1988], La langue et l'information. Paris: Cellule de Recherche en Linguistique.

Karpińska-Szaj K., Wojciechowska B. (2015), La performance morphosyntaxique dans les tâches de reformulation écrite. Cas d'étudiants débutants de FLE (w) „Neofilolog”, nr 44/ 1, s. 73-90.

Karpińska-Szaj K. (2015), Przygotowanie do pracy z uczniami o specjalnych potrzebach edukacyjnych: językowe narzędzia diagnostyczne w praktyce nauczycielskiej (w) „Neofilolog”, nr 45/2, s. 187-202.

Konderak P. (2016), Akwizycja (przyswajanie) języka (w) Bremer J. (red.), Przewodnik po kognitywistyce. Kraków: Wydawnictwo WAM, s. 526-549.

Lahire B. (1992), L'inégalité devant la culture écrite scolaire: le cas de l'expression écrite à l'école primaire (w) „Sociétés contemporaines”, nr 11, s. 171-191.

Langacker R.W. (2009), Gramatyka kognitywna. Wprowadzenie. Kraków: Universitas. Le Cunff C. (2008), Reformuler pour apprendre, apprendre à reformuler: usages didactiques de la reformulation en français langue maternelle $(w)$ Schuwer M., Le Bot M.-C., Richard E. (red.), Pragmatique de la reformulation, types de discours interactions didactiques. Rennes: P.U.R., s. 203-219.

Martinot C. (2012), De la reformulation en langue naturelle, vers son exploitation pédagogique en langue étrangère: pour une optimisation des stratégies d'apprentissage (w) Karpińska-Szaj K., Zając J. (red.), Autour de la compétence d'apprentissage de langues : gestion des ressources métacognitives et cognitives. "Synergies-Pologne”, nr 9, s. 63-76.

M artinot C., M arque-Pucheu Ch., Gerolimich S. (red.) (2016), Perspectives harrissiennes. Paris: Cellule de Recherche en Linguistique. 
M artinot C., Bošnjak B.T., Gerolimich S., Paprocka-Piotrowska U. (red.) (2018), Reformulation et acquisition de la complexité linguistique. Perspective interlangue. Londyn: ISTE, Collection Sciences Cognitives.

Pawlak M . (2011), Text reconstruction activities and teaching language forms (w) Majer J., Salski Ł. (red.), FLOW. Foreign Language Opportunities in Writing. Łódź: Łódź University Press, s. 21-40.

Schmidt R. (1990), The role of consciousness in Second Language Learning (w) „Applied Linguistics", nr 11/2, s. 129-158.

Schmidt R., Frota S. (1986), Developing basic conversational ability in a second language. A case study of an adult learner of Portuguese (w) Day R. (red.), Talking to learn: Conversation in second language acquisition. Rowley, M A: Newbury House, s. 237-326.

Slobin D.I. (1985), Crosslinguistic Evidence for the Language-Making Capacity (w) Slobin D.I. (red.), The Crosslinguistic Study of Language Acquisition, t. 2: Theoretical Issues. Hillsdale, NJ: Lawrence Erlbaum, s. 1157-1249.

Sopata A. (2013), Wczesna wielojęzyczność: rola wieku rozpoczęcia akwizycji języka (w) „Lingwistyka Stosowana/Applied Linguistics/Angewandte Linguistik", nr 7, s. 135-144.

Swain M. (1985), Communicative competence: Some roles of comprehensible input and comprehensible output in its development (w) Gass S.M., Madden C.G. (red.), Input in second language acquisition. Rowley, M A: Newbury House, s. 235-253.

Swain M. (1995), Three functions of output in second language learning (w) Cook G., Seidlhofer B. (red.), Principle and practice in applied linguistics. Oxford: Oxford University Press, s. 125-144.

Swain M ., Lapkin S. (2002), Talking it through: two French immersion learners' response to reformulation (w) "International J ournal of Educational Research", nr 37, s. 285-304.

Tabakowska E. (2016), Językoznawstwo kognitywne - geneza, kierunki i perspektywy (w) Bremer J. (red.), Przewodnik po kognitywistyce. Kraków: Wydawnictwo WAM. s. 79-120.

Thornbury S. (1997), Reformulation and reconstruction: Tasks that promote 'noticing' (w) „ELT Journal”, nr 51, s. 326-335.

Tomasello M. (2003), Społeczno-pragmatyczna teoria uczenia się stów (w) Dąbrowska E., Kubiński W. (red.), Akwizycja języka w świetle językoznawstwa kognitywnego. Kraków: Universitas, s. 211-225.

Tomasello M. (2015) [2009], Dlaczego współpracujemy? Warszawa: Copernicus Center Press.

Widła H. (red.) (2010), Glottodydaktyka jako nauka. „Neofilolog” 34. Wygotski L. (1989) [1934], Myślenie i mowa. Warszawa: Wydawnictwo PWN. 